\title{
THE ESTIMATED QUANTITIES OF BUILDING DEMOLITION WASTE
}

\section{A. SOBOTKA ${ }^{1}$, J. SAGAN ${ }^{2}$, A. RADZIEJOWSKA ${ }^{3}$}

The aim of the article is to analyze existing foreign experiences presented in the literature in the field of estimating demolition waste and their applicability in Poland condition. Using the case study method for more than a dozen objects, the authors prove the necessity to verify the suitability of the proposed models in relation to regional conditions (e.g. climatic conditions, local technologies, etc.). The amount of concrete waste from demolition of objects made in the analyzed technology is characterized by a low coefficient of variation, especially in the case of public facilities and is only $10 \%$. However, in the case of residential buildings, the volatility was $16,7 \%$. The calculated average index of concrete waste was compared with the two literature models. The results obtained differ from the values obtained from the models. Based on an analysis of the advantages and disadvantages of the selected models and their assumptions, a proposal has been formulated for the development of an effective tool for estimating demolition waste taking into account regional specific conditions together with the concept of sustainable construction. The focus was on waste from demolition of concrete objects.

Key words:

Keywords: demolition waste, estimate models, concrete waste, sustainable construction

\footnotetext{
${ }^{1}$ Prof., DSc., Eng., AGH University of Science and Technology in Cracow, Department of Geomechanics, Civil Engineering and Geotechnics, Av. Mickiewicza 30, 30-059 Cracow, Poland, e-mail: sobotka@agh.edu.pl

${ }^{2}$ PhD., Eng., AGH University of Science and Technology in Cracow, Department of Geomechanics, Civil Engineering and Geotechnics, Av. Mickiewicza 30,30-059 Cracow, Poland, e-mail: czajaj@agh.edu.pl

${ }^{3}$ PhD., Eng., AGH University of Science and Technology in Cracow, Department of Geomechanics, Civil Engineering and Geotechnics, Av. Mickiewicza 30,30-059 Cracow, Poland, e-mail: aradziej@agh.edu.pl
} 


\section{INTRODUCTION}

The modern concept of sustainable growth needs effective waste management with waste recovery. A basic requirement for the implementation of waste recovery processes is waste segregation. In construction projects, demolition work with waste segregation involves higher operating costs at the demolition stage than in the case of classic demolition [8]. However, selectively collected waste gives the opportunity to compensation costs incurred at the stage of waste management.

Segregated building materials from demolition have the market value of recycled raw materials, especially for concrete aggregate (RCA) [9]. Profit from the sale of recovered materials and avoidance of costs for waste utilization reduce operating costs of demolition.

The value of recycled materials as well as the costs of waste disposal are important elements of a construction project involving the demolition of a facility and, therefore, needs a quantitative and qualitative assessment of the generated waste in accordance with the waste catalog [18]. In the initiation phase of the demolition of a building, due to financial and logistical reasons, it is important to forecast the amount of generated waste for each material type [22].

In Poland, facilities currently subjected to demolition usually have only paper documentation, often incomplete, from which the estimation of the amount of waste from their demolition requires tedious analysis or survey in the field. The development of methods with sufficient accuracy for estimating the amount of waste from demolition of a building can significantly improve this process.

World's literature, publishes verified models for estimating the amount of waste from demolition. However, due to different climate conditions, technological practices, and adopted national project approaches, using these models in domestic conditions requires their verification. The aim of the article is to analyze existing literature models for demolition waste estimation. Using the "case study" method for more than a dozen objects, the authors in this publication show that literature models of waste estimation do not always apply to domestic conditions. The article analyzes the advantages and disadvantages of selected literature models and the reasons for model result discrepancies in Poland and other European countries. To build regional models, the paper presents a proposal to develop an effective tool for estimating demolition waste, taking into account specific construction conditions in Poland. 


\section{LITERATURE REVIEW}

An important element of a construction project involving the demolition of a facility is the quantitative and qualitative assessment of the generated waste $[7,19,21]$. This assessment is also needed for rational waste management in a given region $[2,24]$. Despite the importance of the problem, it has not yet found a sufficiently large interest and exhaustive literature on the subject.

A few studies in this respect, mainly foreign, provide methods for determining the amount of waste in construction projects [17]. However, it is necessary to distinguish between models dedicated to waste generated during construction of facilities from those dedicated to waste generated in demolition processes. In this publication, attention is given to the models for objects no longer used and subjected to demolition.

Assessment of waste from the demolition of a facility is needed, as already mentioned in Chapter 1, for many reasons, not only economic - expected profits, e.g., from sales and/or their utilization. It is necessary to assess the amount of waste, as well as their quality, from the point of view of technology planning and organization of construction works, i.e., taking into account demolition, necessary teams of workers, available equipment with construction equipment and machines, the organization of technological lines for waste recycling at the construction site and the organization of reverse logistics chains.

Simple estimation tools that rely on estimation tables can be found in publications such as $[1,11,13,15]$, their advantage being universality and ease of use. Estimation tables give estimated quantities (waste averages) in $\mathrm{m}^{3}$ or $\mathrm{Mg}$ as a function of selected parameters of the estimated building (surface area, volume, etc.). Also, software codes such as ITeC [3] and SmartWasteTM [4] are used. Different approach to assess the amount of waste based on investment costs was proposed by Wang [23]. Out of these tools, none has been widely applied in Polish conditions.

Another publication recommends improving technical documentation that should be prepared during building development or expansion in each phase of the life cycle (and, therefore, also in the operation phase), BIM technology (Building Information Modeling/Management). Such improved documentation may better support decisions to choose architects and investor's construction technologies (at the programming, planning, and design stages) in accordance with the requirements of sustainable construction and effective waste management. The use of BIM technology will allow for easy and accurate assessment of the amount of construction waste arising from the demolition of facilities $[6,7,12,14,16]$. However, this approach does not apply to objects that do not have a 3D model, which applies to most of disassembled buildings in Poland, which 
very often do not have the current technical documentation of the facility at all. Such a status forces to look for methods for estimating waste.

\section{THE USEFULNESS OF THE TOOLS FOR ESTIMATING THE QUANTITY OF WASTE FROM THE DEMOLITION WORKS}

During the initiation phase of the demolition of a building, due to financial and logistical reasons and due to the selection of technological solutions, it is important to forecast the amount of generated waste for each specific type (Fig. 1).

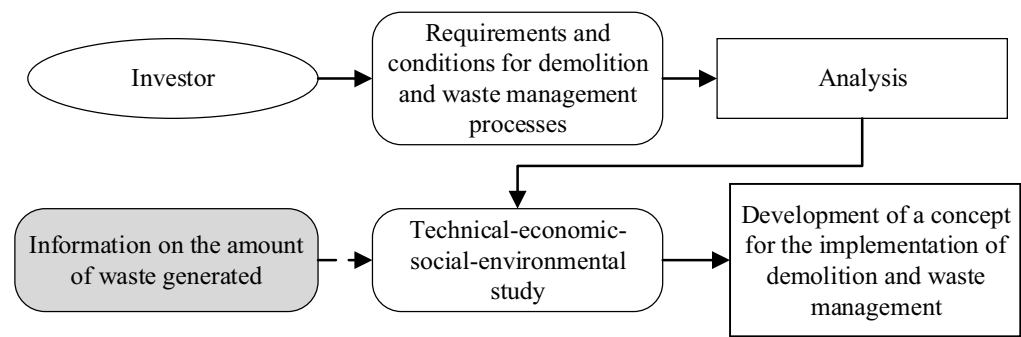

Fig. 1. Forecasting the amount of waste in the initiation phase of a demolition project.

Based on [20]

In practice, objects subjected to demolition do not have a complete technical documentation; hence, the process of waste estimation is a complex process and requires an actual inventory of the object or other work. The use of adequate, ready-to-use models would significantly improve the work of individual participants of the construction project. Fig. 2 presents a diagram of the use of waste estimation models in the study phase of the implementation of the demolition project of waste management. The area of the model's operation includes the cost estimator's work of quantitative waste assessment. The results of the assessment are input data into analyzes carried out by the planner of logistics of the construction site (required waste storage sites) and preliminary schedule of waste management processes. On this basis, together with input of prices for recovered materials and of savings from avoiding waste utilization, it is possible to develop a concept for the implementation of waste management processes. 


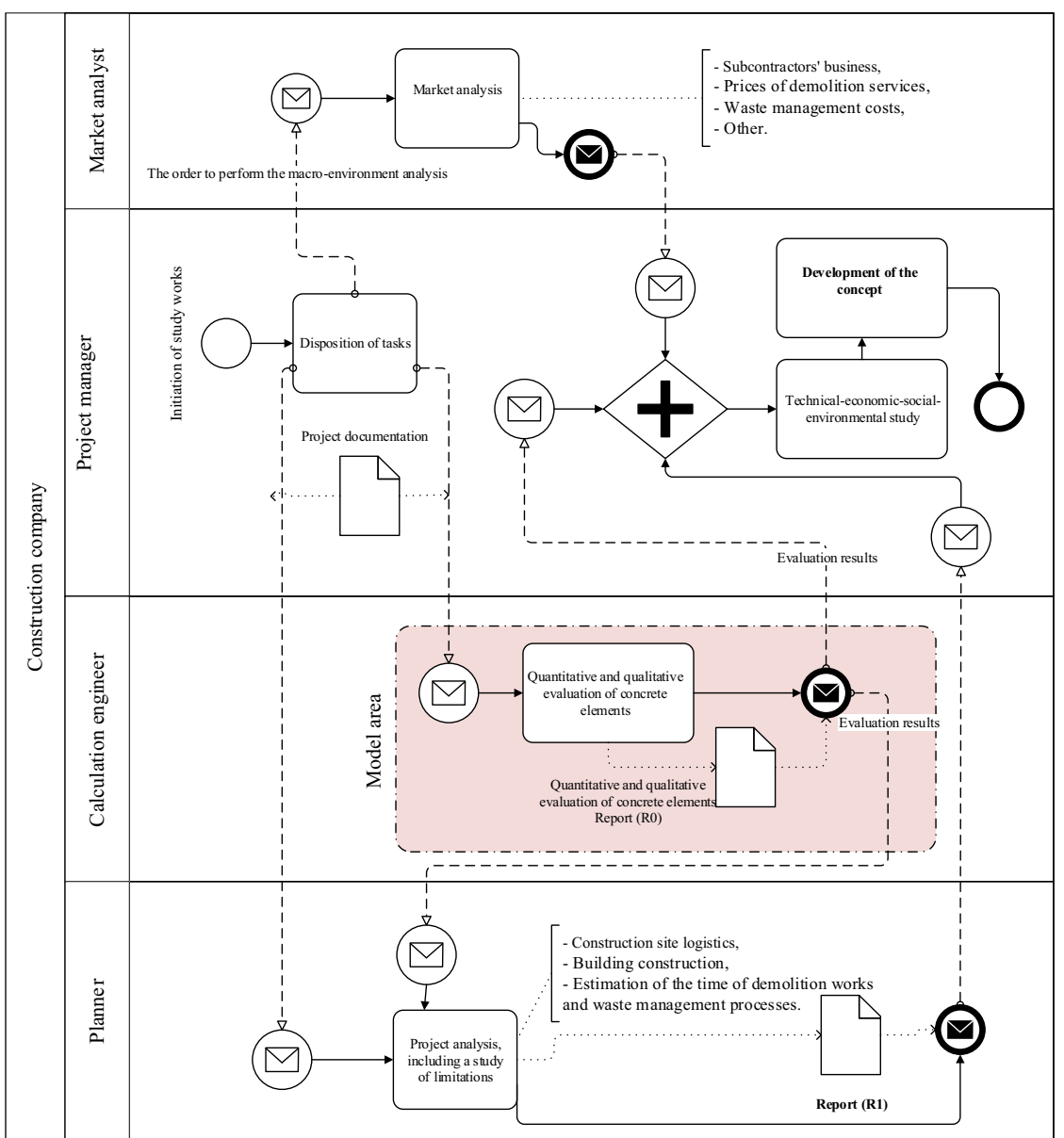

Fig. 2. The use of models for estimating the amount of waste in the study phase of the demolition project - BPMN notation

The predictive models can also be used in the creation of scenarios for the life cycle of building objects, or as an element of a simulation program supporting decision in the field of waste management from demolition. However, it should be aware that such models cannot be used in atypical facilities. 


\section{ASSESSMENT OF SELECTED METHODS OF ESTIMATING WASTE IN DOMESTIC CONDITIONS}

Due to the diversity of the construction of buildings (dimensions of individual elements, their spacing, etc.) located in different regions (countries) and constructed in different periods of time, using the same or different technologies, the models can't be used uncritically. Differences in facilities may occur not only for climatic reasons but also for different legal requirements. Therefore, this chapter examines and analyzes the methods for estimating quantities of waste that are used in other countries in relation to the possibility of using them for conditions of construction specificity in Poland.

As part of such verification, the models developed by 3D/International [1] and Llatas [17] were analyzed. Both models are based on correlations of the amount of waste with the usable area of an object. The scope of the verification includes only concrete waste coming from cubature objects:

a) non-residential buildings (public utility), made in monolithic technology. In this case, all structural elements of building (ceilings, columns, beams, walls, etc.) were made of reinforced concrete. The purpose of the buildings were nurseries, kindergartens and offices.

b) residential buildings, made in traditional improved technology (some structural elements of the objects were made using ceramic materials, e.g. external walls, ceiling filling).

In the model presented in [1] for estimating the amount of concrete waste $\left(Q_{\text {concrete }}\right)$ the following formula is used:

$$
Q_{\text {Concrete }}=P_{\text {concrete }} \cdot A \cdot G_{\text {ave }} \cdot 0.0005
$$

where:

$A$ - the project square footage (sf), $G_{\text {ave }}$ - weighted average waste generation rate (lb/sf) (a function of the type of building: residential/non-residential), 0.0005 - conversion factor from lbs to tons, $P_{\text {concrete }}$ - share of concrete in total waste mass (a function of the building type).

In turn, the Llatas model [17] gives a quantitative assessment of waste based on estimation tables as a function of weighted average $C \& D$ waste generation rates $\left(\mathrm{kg} / \mathrm{m}^{2}\right)$, and average percentage of waste composition by volume in demolitions (\%). Selected data from the Llatas study are compared with the results of the authors' research and are presented in Table 1 in intervals 
(from-to) and divided into light and heavy structures as well as residential and non-residential buildings.

In the first stage of the verification tests, the analysis of the documentation of 19 buildings made in Poland (10 residental, 9 non-residental) confirmed a significant determination coefficient between the amount of concrete waste and the usable area of objects (Fig. 3).

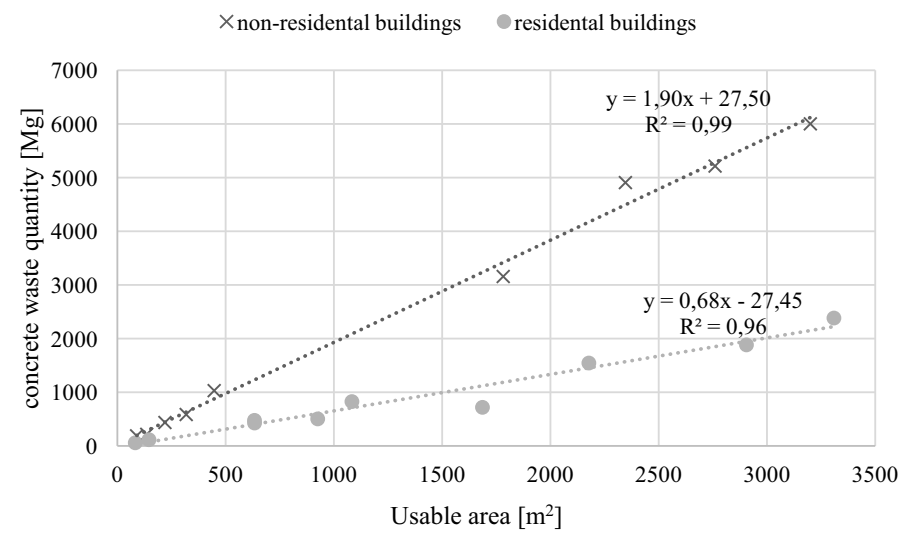

Fig. 3. Analysis of the correlation and regression of the quantity of concrete waste as a function of the usable area of cubature objects

The obtained distribution of statistical measures of the concrete waste rate (concrete waste quantity/usable area) in the sample tested is presented in Fig. 4. The amount of concrete waste from demolition of objects made in the analyzed technology is characterized by a low coefficient of variation, especially in the case of public facilities and is only $10 \%$. However, in the case of residential buildings, the volatility was $16,7 \%$. 

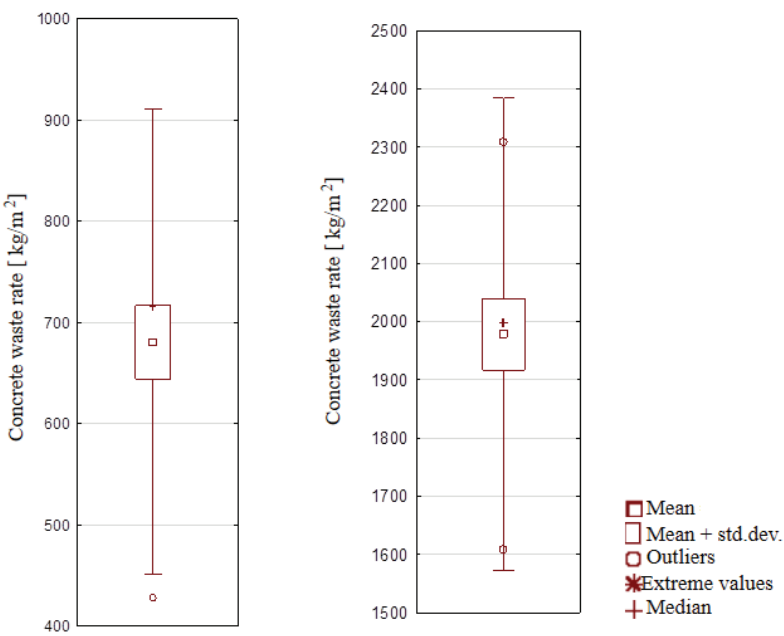

Fig. 4. Distribution of statistical measures of the concrete waste rate in the reviewed sample; on the left for residential buildings, on the right for non-residential buildings.

The calculated average index of concrete waste was compared with the two discussed literature models. The results obtained differ from the values obtained from the models 3D/International 2012 and Llatas (Table 1). A good agreement of the results is obtained only for residential buildings, using the model presented in [17]. The estimated amounts of concrete waste for non-residential buildings made in monolithic concrete technology obtained from the two models are significantly underpredicting the results obtained by the authors of this article.

Table 1. Comparison of test results

\begin{tabular}{ccccc}
\hline \multirow{2}{*}{$\begin{array}{c}\text { amount of waste } \\
\text { generated: }\end{array}$} & $\begin{array}{c}\text { (3D/International 2012) } \\
{\left[\mathrm{kg} / \mathrm{m}^{2}\right]}\end{array}$ & $\begin{array}{c}(\text { Llatas } 2014)^{4} \\
{\left[\mathrm{~kg} / \mathrm{m}^{2}\right]}\end{array}$ & $\begin{array}{c}\text { monolithic } \\
\text { technology }\left[\mathrm{kg} / \mathrm{m}^{2}\right]\end{array}$ & $\begin{array}{c}\text { traditional improved } \\
\text { technology }\left[\mathrm{kg} / \mathrm{m}^{2}\right]\end{array}$ \\
\hline non-residental: & 442 & $\begin{array}{c}600-810 \\
\text { (heavyweight) }\end{array}$ & 1978 & - \\
\hline residental: & 167 & $\begin{array}{c}480-750 \\
\text { (heavyweight) }\end{array}$ & - & 681 \\
\hline
\end{tabular}

The differences of results come from assumptions in all the models and include regional differences, mostly climatic conditions. These conditions affect the applied structural and technological solutions as well as the approaches adopted in the design of construction works in Poland.

\footnotetext{
${ }^{4}$ Assuming bulk density of concrete debris $1500 \mathrm{~kg} / \mathrm{m}^{3}$
} 
Different regional climatic zones determine the variability of building loads (wind load, snow load) and of the exposure class of the lag thickness. European standards [5] for structural design allow for specifying regional differences regarding these loads, as well as accepted safety factors, which ultimately translate into the massiveness of the structure and the future amount of demolition waste. The technology in which the building was erected and finished is not without significance. For illustration, the material diversity of facilities traditionally used in the EU is provided by statistics on the amount of waste generated (Table 2).

Table 2. Share of materials in the structure of construction waste in EU countries [10]

\begin{tabular}{ccc}
\hline Type of waste & $\%-$ Min & $\%-$ Max \\
\hline Concrete & $12 \%$ & $40 \%$ \\
Brick & $8 \%$ & $54 \%$ \\
Wood & $2 \%$ & $4 \%$ \\
Metal & $2 \%$ & $4 \%$ \\
Gypsum & $0,2 \%$ & $0,4 \%$ \\
Other & $2 \%$ & $36 \%$ \\
\hline
\end{tabular}

The above-mentioned results show that the literature models cannot be used uncritically and they require verification for Polish conditions. Alternatively, development of new models for domestic conditions is needed.

\section{SUMMARY AND CONCLUSIONS}

Different approaches can be found in estimating the amount of waste. One of them assumes a correlation of waste as a function of building parameters, while others are based on financial models. Due to the dynamic nature of the market, it seems more reasonable to apply an approach based on the correlation of the amount of waste with the technical parameters of the construction works, as seen from the authors' correlation, Fig. 1. Due to rules and standards (requirements) applied at the design stage of the facility for a given technology and time, there is a certain repeatability of quantity and quality of materials used in a given technology. Therefore, the proposal for further development of models for domestic conditions is presented as a process comprising: 
1. Specification of building technologies commonly found in the country,

2. Specification of a group of objects at their end of use,

3. Research on the correlation of the amount of waste of a specific type (broken down according to the waste catalog) with the selected reference value,

4. Analysis of adaptability of existing models,

5. Acceptance of a ready model or a development of a new (regional) model.

In the development of tools it is recommended to include information about the range of variability of the average value of the waste rate. In contrast to the estimation tables commonly found in the literature, statistical models have the advantage that they enable the estimation of operational risk (logistic, financial, etc.) of waste management.

As noticed above, existing models use waste volume. Such an approach finds its justification in logistic issues such as waste storage and transport, where for materials with low bulk density waste volume will largely determine these processes. However, waste volume affects its bulk density, which changes depending on the technology of demolition works and, then, in the process of waste treatment. In addition, in Poland, the prices for accepting waste for disposal are expressed per unit of mass. Therefore, it is recommended that the waste amount indicators be expressed in mass units per selected reference value, e.g. $\mathrm{m}^{2}$. For non-residential buildings, the amounts of waste should be given per cubic meter due to differences in height.

\section{REFERENCES}

1. 3D/International, "C\&D Waste Management pocket guide," 2012.Elaboration prepared for HQ AFCEE/EQ.

2. G. Banias, C. Achillas, C. Vlachokostas, N. Moussiopoulos, and S. Tarsenis, "Assessing multiple criteria for the optimal location of a construction and demolition waste management facility," Build. Environ., vol. 45, no. 10, pp. 2317-2326, 2010.

3. BEDEC, "ITeC database of construction elements," 2016. [Online]. Available: https://en.itec.cat/database/. [Accessed: 17-Oct-2018].

4. BRE, "SmartWaste," 2017. [Online]. Available: http://www.smartwaste.co.uk/. [Accessed: 22-Oct-2018].

5. CEN, "EN 1991 Eurocode 1: Actions on structures."

6. J. C. P. Cheng and L. Y. H. Ma, "A BIM-based system for demolition and renovation waste estimation and planning,” Waste Manag., vol. 33, no. 6, pp. 1539-1551, Jun. 2013.

7. J. C. P. Cheng, J. Won, and M. Das, "Construction and demolition waste management using BIM technology," 23rd Annu. Conf. Int. Gr. Lean Constr., no. July, 2015.

8. A. Coelho and J. De brito, "7 - Conventional demolition versus deconstruction techniques in managing construction and demolition waste (CDW)," in Handbook of Recycled Concrete and Demolition Waste, F. Pacheco-Torgal, V. W. Y. Tam, J. A. Labrincha, Y. Ding, and J. de Brito, Eds. Woodhead Publishing, pp. $141-185,2013$.

9. X. H. Deng, Z. L. Lu, P. Li, and T. Xu, "An Investigation of Mechanical Properties of Recycled Coarse Aggregate Concrete,” Arch. Civ. Eng., vol. 62, pp. 19-34, 2016.

10. European Commission (DG ENV), "A project under the Framework contract ENV.G.4/FRA/2008/0112," 2011.

11. Franklin Associates, "Characterisation of Building Related Construction and Demolition Debris in the United States". 1998. 
12. A. Glema „Building information modeling BIM - level of digital construction”. Archives of Civil Engineering, no 3,2017 , pp. 39-51.

13. Homestead FL, "Construction Waste Management Handbook,” 2012.

14. T. Howiacki, "BIM w projektowaniu konstrukcji żelbetowych - zarys zagadnienia," 2018.

15. Innovative Waste Management, "Construction Materials Recycling Guidebook," Minneapolis, 1993.

16. F. Jalaei and A. Jrade, "Construction Research Congress 2014 CASCE 2014 140,” Constr. Res. Congr. 2014, no. 2008, pp. 140-149, 2014.

17. C. Llatas, "Methods for estimating construction and demolition (C\&D) waste," Handb. Recycl. Concr. demolition waste, pp. 25-52, 2014.

18. Minister Środowiska, Rozporządzenie Ministra Środowiska z dnia 9 grudnia 2014 r. w sprawie katalogu odpadów (Dz.U. 2014 poz. 1923). pp. 1-47, 2014.

19. Z. Orłowski and E. Pawluczuk, "Wpływ sposobu wyburzania obiektów na łatwość segregacji i recyklingu odpadów,” Zesz. Nauk. Politech. Białostockiej. Bud., vol. Z. 27, pp. 239-248, 2006.

20. Praca zbiorowa pod redakcją Tadeusza Kasprowicza, Inżynieria predsięwzięćc budowlanych. Rekomendowane metody i techniki. Warszawa, 2015.

21. A. Sobotka and J. Czaja, "Analysis of the Factors Stimulating and Conditioning Application of Reverse Logistics in Construction," Procedia Eng., vol. 122, no. Supplement C, pp. 11-18, 2015.

22. A. Sobotka, J. Sagan, M. Baranowska, and E. Mazur, "Management of reverse logistics supply chains in construction projects," Procedia Eng., vol. 208, pp. 151-159, 2017.

23. J. Y. Wang, A. Touran, C. Christoforou, and H. Fadlalla, "A systems analysis tool for construction and demolition wastes management," Waste Manag., vol. 24, no. 10, pp. 989-997, Jan. 2004.

24. P. A. Yost and J. M. Halstead, “A methodology for quantifying the volume of construction waste," Waste Manag. Res., vol. 14, no. 5, pp. 453-461, Oct. 1996.

\section{LIST OF FIGURES AND TABLES:}

Fig. 1. Forecasting the amount of waste in the initiation phase of a demolition project. Based on [20]

Rys. 1. Prognozowanie ilości odpadów w fazie inicjacji przedsięwzięcia rozbiórki. Na podstawie [20]

Fig. 2. The use of models for estimating the amount of waste in the study phase of the demolition project - BPMN notation

Rys. 2. Zastosowanie modeli do szacowania ilości odpadów w fazie studialnej przedsięwzięcia rozbiórki obiektu - notacja BPMN

Fig. 3. Analysis of the correlation and regression of the quantity of concrete waste as a function of the usable area of cubature objects

Rys. 3. Analiza korelacji i regresji ilości odpadów betonowych z powierzchnią użytkową obiektów kubaturowych

Fig. 4. Distribution of statistical measures of the concrete waste rate in the reviewed sample; on the left for residential buildings, on the right for non-residential buildings.

Rys. 4. Rozkład miar statystycznych wskaźnika odpadów betonowych w badanej próbie; po lewej dla obiektów mieszkalnych, po prawej dla obiektów niemieszkalnych

Tab. 1. Comparison of test results

Tab. 1. Porównanie wyników badań

Tab. 2. Share of materials in the structure of construction waste in EU countries [10]

Tab. 2. Udział materiałów w strukturze odpadów budowlanych w krajach UE [10] 


\section{SUMMARY:}

The modern concept of sustainable growth needs effective waste management with waste recovery. A basic requirement for the implementation of waste recovery processes is waste segregation. In construction projects, demolition work with waste segregation involves higher operating costs at the demolition stage than in the case of classic demolition [8]. However, selectively collected waste gives the opportunity to compensation costs incurred at the stage of waste management.

The value of recycled materials as well as the costs of waste disposal are important elements of a construction project involving the demolition of a facility and, therefore, needs a quantitative and qualitative assessment of the generated waste in accordance with the waste catalog [18]. In the initiation phase of the demolition of a building, due to financial and logistical reasons, it is important to forecast the amount of generated waste for each material type [22].

World's literature, publishes verified models for estimating the amount of waste from demolition. However, due to different climate conditions, technological practices, and adopted national project approaches, using these models in domestic conditions requires their verification. The aim of the article is to analyze existing literature models for demolition waste estimation. Using the "case study" method for more than a dozen objects, the authors in this publication show that literature models of waste estimation do not always apply to domestic conditions. The basis for such a statement are the results contained in Table 1. Compatibility of results was obtained only for residential buildings, using the model presented in [17]. The estimated amount of concrete waste for non-residential buildings made in monolithic concrete technology is significantly different from the research results obtained.

Table 1. Comparison of test results

\begin{tabular}{|c|c|c|c|c|}
\hline \multirow[b]{2}{*}{$\begin{array}{l}\text { amount of waste } \\
\text { generated: }\end{array}$} & \multirow[b]{2}{*}{$\begin{array}{c}\text { (3D/International 2012) } \\
{\left[\mathrm{kg} / \mathrm{m}^{2}\right]}\end{array}$} & \multirow{2}{*}{$\begin{array}{c}(\text { Llatas 2014) } \\
{\left[\mathrm{kg} / \mathrm{m}^{2}\right]}\end{array}$} & \multicolumn{2}{|c|}{ Own calculation } \\
\hline & & & $\begin{array}{c}\text { monolithic } \\
\text { technology }\left[\mathrm{kg} / \mathrm{m}^{2}\right]\end{array}$ & $\begin{array}{l}\text { traditional improved } \\
\text { technology }\left[\mathrm{kg} / \mathrm{m}^{2}\right]\end{array}$ \\
\hline non-residental: & 442 & $\begin{array}{c}600-810 \\
\text { (heavyweight) }\end{array}$ & 1978 & - \\
\hline residental: & 167 & $\begin{array}{c}480-750 \\
\text { (heavyweight) }\end{array}$ & - & 681 \\
\hline
\end{tabular}

The differences of results come from assumptions in all the models and include regional differences, mostly climatic conditions. These conditions affect the applied structural and technological solutions as well as the approaches adopted in the design of construction works in Poland.

\footnotetext{
${ }^{5}$ Assuming bulk density of concrete debris $1500 \mathrm{~kg} / \mathrm{m}^{3}$
} 
Different approaches can be found in estimating the amount of waste. One of them assumes a correlation of waste as a function of building parameters, while others are based on financial models. Due to the dynamic nature of the market, it seems more reasonable to apply an approach based on the correlation of the amount of waste with the technical parameters of the construction works, as seen from the authors' correlation, Fig. 1. Due to rules and standards (requirements) applied at the design stage of the facility for a given technology and time, there is a certain repeatability of quantity and quality of materials used in a given technology. Therefore, the proposal for further development of models for domestic conditions is presented as a process comprising:

1. Specification of building technologies commonly found in the country,

2. Specification of a group of objects at their end of use,

3. Research on the correlation of the amount of waste of a specific type (broken down according to the waste catalog) with the selected reference value,

4. Analysis of adaptability of existing models,

5. Acceptance of a ready model or a development of a new (regional) model.

In the development of tools it is recommended to include information about the range of variability of the average value of the waste rate. In contrast to the estimation tables commonly found in the literature, statistical models have the advantage that they enable the estimation of operational risk (logistic, financial, etc.) of waste management.

As noticed above, existing models use waste volume. Such an approach finds its justification in logistic issues such as waste storage and transport, where for materials with low bulk density waste volume will largely determine these processes. However, waste volume affects its bulk density, which changes depending on the technology of demolition works and, then, in the process of waste treatment. In addition, in Poland, the prices for accepting waste for disposal are expressed per unit of mass. Therefore, it is recommended that the waste amount indicators be expressed in mass units per selected reference value (e.g. $\mathrm{m}^{2}$ of usable area). 


\section{SZACOWANIE ILOŚCI ODPADÓW Z ROZBIÓREK KUBATUROWYCH}

Slowa kluczowe: odpady z rozbiórki, modele szacunkowe, odpady betonowe, zrównoważone budownictwo

\section{STRESZCZENIE:}

Prowadzenie efektywnej gospodarki odpadami ukierunkowanej na ich odzysk, jest realizacją współczesnej koncepcji zrównoważonego rozwoju. Podstawowym wymaganiem realizacji procesów odzysku odpadów jest ich selekcja. W przedsięwzięciach budowlanych prowadzenie prac rozbiórkowych w systemie dekonstrukcji z selekcją odpadów wiąże się z ponoszenie większych kosztów operacyjnych na etapie rozbiórki obiektu niżeli w przypadku klasycznego wyburzenia [8]. Selektywnie zebrane odpady dają jednak możliwość rekompensaty poniesionych kosztów na etapie gospodarowania nimi.

Wartość surowców z odzysku jak i koszty utylizacji odpadów są zróżnicowane, stąd ważnym elementem przedsięwzięcia budowlanego polegającego na rozbiórce obiektu jest więc ocena ilościowa i jakościowa generowanych odpadów zgodnie z katalogiem odpadów [18].

W światowej literaturze przedmiotu można odnaleźć opracowane modele do szacowania ilości odpadów z rozbiórek obiektów i mają one dobre doświadczenia w tym względzie. Jednak, $\mathrm{z}$ uwagi na zmienne uwarunkowania klimatyczne, tradycje technologiczne, oraz przyjęte (krajowe) podejścia projektowe, możliwość zastosowania tych modeli w warunkach krajowych wymaga co najmniej ich weryfikacji. Celem artykułu jest analiza istniejących doświadczeń w zakresie szacowania odpadów. Skoncentrowano się na odpadach z rozbiórek obiektów betonowych. Stosując metodę „case study” dla kilkunastu obiektów, autorki w niniejszej publikacji dowodzą o braku możliwości bezkrytycznego zastosowania istniejących modeli szacowania odpadów do warunków krajowych. Podstawą do takiego stwierdzenia są wyniki zawarte w tabeli 1. Zgodność wyników uzyskano jedynie wobec obiektów mieszkalnych, przy zastosowaniu modelu przedstawionego w [17]. Szacowana ilość odpadów betonowych dla obiektów niemieszkalnych wykonanych w technologii betonowej monolitycznej w sposób istotny odbiega od wyników badań autorek artykułu (własnych).

Tabela 1. Porównanie wyników badań z literatury i własnych

\begin{tabular}{|c|c|c|c|c|}
\hline \multirow{2}{*}{$\begin{array}{l}\text { Ilość generowanych } \\
\text { odpadów: }\end{array}$} & \multirow{2}{*}{$\begin{array}{c}\text { (3D/International 2012) } \\
{\left[\mathrm{kg} / \mathrm{m}^{2}\right]}\end{array}$} & \multirow{2}{*}{$\begin{array}{c}(\text { Llatas 2014) } \\
{\left[\mathrm{kg} / \mathrm{m}^{2}\right]}\end{array}$} & \multicolumn{2}{|c|}{ Wyniki własne } \\
\hline & & & $\begin{array}{c}\text { Tech. monolityczna } \\
{\left[\mathrm{kg} / \mathrm{m}^{2}\right]}\end{array}$ & $\begin{array}{c}\text { Tech. tradycyjna } \\
\text { udoskonalona }\left[\mathrm{kg} / \mathrm{m}^{2}\right]\end{array}$ \\
\hline $\begin{array}{c}\text { Budynki } \\
\text { niemieszkalne: }\end{array}$ & 442 & $600-810$ & 1978 & - \\
\hline $\begin{array}{c}\text { Budynki } \\
\text { mieszkalne: }\end{array}$ & 167 & $480-750$ & - & 681 \\
\hline
\end{tabular}

\footnotetext{
${ }^{6}$ Przy założeniu gęstości nasypowej gruzu betonowego $1500 \mathrm{~kg} / \mathrm{m}^{3}$
} 
Zróżnicowanie wyników nie przesądza o nieprawidłowościach modelu wybranego do oceny możliwości wykorzystania w specyfice budownictwa polskiego, a raczej jest skutkiem różnic regionalnych, których autorki dopatrują się przede wszystkim w zakresie uwarunkowań klimatycznych. Wpływają one na stosowane rozwiązanie konstrukcyjne i technologiczne oraz przyjęte w Polsce podejścia w projektowaniu obiektów budowlanych.

W szacowaniu ilości odpadów odnaleźć można zróżnicowane podejścia. Jedne z nich zakładają korelację odpadów w odniesieniu do parametrów budynku, inne zaś bazują na modelach finansowych. Ze względu na dynamiczny charakter rynku, rozsądniejszym zdaje się być stosowanie podejścia opartego na korelacji ilości odpadów z parametrami technicznymi obiektów budowlanych (w badaniach widoczny jest wysoki wskaźnik wspomnianej korelacji). Z uwagi na pewien zbiór zasad i norm (wymagań) przestrzeganych na etapie projektowania obiektu w danej technologii i czasie, istnieje pewna powtarzalność w zakresie ilości i jakości stosowanych materiałów w danej technologii. Stąd też, propozycję dalszej rozbudowy modeli krajowych przedstawia się $\mathrm{W}$ postaci procesu obejmującego: wyszczególnienie technologii budynków powszechnie występujących w kraju, identyfikacja grupy obiektów wychodzących z użytkowania, badanie korelacji ilości odpadów określonego rodzaju (w podziale zgodnym z katalogiem odpadów) z wybraną wielkością odniesienia, analizę adaptacyjności istniejących modeli, przyjęcie gotowego modelu lub budowę modeli własnych (regionalnych).

W budowie narzędzi zaleca się zawierać informacją o zakresie zmienności wartości średniej wskaźnika odpadów. W odróżnieniu do często spotykanych w literaturze tabel estymacyjnych, modele statystyczne mają tę zaletę, że umożliwiają szacowanie ryzyka operacyjnego (logistycznego, finansowego, itp.) gospodarki odpadami.

Jako zauważone wady istniejących modeli wymienić należy operowanie jednostką objętości odpadów. Takie podejście znajduje swoje uzasadnienie w kwestiach logistycznych takich jak magazynowanie odpadów i ich transport, gdzie w przypadku materiałów o niewielkiej gęstości nasypowej będzie to kryterium warunkujące przebieg wspomnianych procesów. Należy jednak zauważyć, że frakcja odpadu warunkuje jego gęstość nasypową, która może zmieniać się w zależności od technologii robót rozbiórkowych oraz następnie, w procesie przetwarzania odpadów. Dodatkowo, w Polsce ceny przyjęcia odpadów do utylizacji również wyrażone są na jednostkę masy. Zaleca się więc, aby wskaźniki ilości odpadów były wyrażane w jednostkach masy na wybraną wielkość odniesienia (np. $\mathrm{m}^{2}$ powierzchni użytkowej). 